\title{
Land use planning for utilizing biomass residues in Tuscia Romana (cen- tral Italy): preliminary results of a Multi Criteria Analysis to create an agro-energy district.
}

\begin{abstract}
This study provides a preliminary agro-environmental, economic and energetic analysis to critically evaluate the biomass potential ofan area of central Italy (Tuscia Romana). This area is selected as representative foragro-forestry from its orographic characteristics, climatic conditions, land use and potential energy sources. Accordingly, the model we have obtained could be used forother similar areasof central Italy. We have assessed the potential agro-forestry biomass availability, energy potential and transport infrastructure using multi criteria analysisand geographic information system approaches. Finally,optimum locations to develop an energy plant were identified. This model could be applied at alocal levelto help deliver environmental policy.
\end{abstract}

Key words: Land use management,Agro-energy district, Multi Criteria Analysis, Biomass.

\section{Introduction}

\section{International and National policy}

Currently, biomass for energy use contributes 10 to $12 \%$ of the world energy balance, but the amount consumed is about $40 \%$ of the usable potential. On a global scale, this potential is approximately $1 / 3$ of today's consumption of conventional energy sources (Hall et al., 1995; EC, 2012; Pignatelliet al., 2014; Salvati et al., 2015).

In a territorial system, two main sources of biomass origin are identifiable:

- Forests

- Agricultural territories.

Energy exploitation of these sources is possible so long as the actions are sustainable. In particular the critical factors related to the interaction between exploitation and land conservation should be considered.In both productive systems, industrialplantsmay produce large quantities of waste (wood processing, food processing, etc.). The reuse of these residues may be an optimal solution for the environment and for the benefit of various production chains.Bioenergy in general, and agro-energy in particular, as with other renewable energy sources, is not necessarily "positive" in environmental terms. A bad system of production and use of renewable sources can be just harmful to the environment as a fossil fuel.

Biomass penetration of energy markets depends not only on suitable exploitation of the energy component, but also on detailed planning that takes into account factors such as: geological and climatic characteristics of the considered area, the potential sources, crop economics, alternative fuels markets, the local energy needs, environmental degradation in the area, etc. Then potential prob- 
lems with the adopted technology are to be examined by checking macroeconomic and "macroecological" aspects (Hummel, 1988; Ministerial Degree n. 9800/2012; Recanatesi et al., 2014; Benstenet al., 2015).

Assessment of the national biomass availability is made difficult not only by the current lack of reliable official data (and this difficulty is also found in the evaluationof its use), but also by a conceptual point:whether "available" is the total availability of biomass in the territory (potential availability), or whether it is the availability which is technically and economically viable.With a gradual transition of responsibilities in renewable energy sources (and therefore also of biomass) from the State to the Regions, a stronger commitment from the government in initiating studies and accurate research, to evaluate the territorial assessment and planningmight have been expected. Instead Energy Plans of Regions (or similar planning documents) are, in most cases, extremely superficial in this kind of analysis and, in many cases, the data are actually unusable (Pignatelliet al., 2014; Bilgiliet al., 2015).

There is not yet a complete and comprehensive set of technical standards for bioenergy, despite the efforts in recent years, both at National and European level, from the various institutions responsible for technical standards such as:

- ISO (International Organization for Normalization), which operates worldwide;

- CEN (ComitéEuropéen de Normalisation), for European regulation;

- UNI (National Unification), in Italy, which includes the CTI (Italian Heat Technology Committee - Energy and Environment) and, with specific reference to biofuels, the CUNA (Technical Commission Unification Motorcar).

The reasons for this incomplete and not always satisfactory technical standards production are manifold; the most significant are:

- the complexity of bioenergysystems,resulting from multiple raw materials, conversion technologies and end-use;

- the confusion between residual biomass a production cycle, its use for energy, and wastes which must or can be discarded;

- the legal vacuum, at the agro-forestry level, about the use of dedicated energy crops, in spite of policy documents at European level which allocate to these crops a large proportion of the future biomass contribution to energy balances;

- the overlapping of National and European standards, that often forces the national standardization bodies to withdraw or revise regulations that have been enacted.

According to a FAO report concerning the state of the world's forest resources (2010), the Italian forests covers a total area of about 11 million hectares, accounting for $36.2 \%$ of entire national territory. The areas occupied by forest formations have seen in the last 50 years a very significant increase, from 5.5 million hectares in 1959 to 10.4 million hectares in 2000, so have essentially doubled in the space of forty years (Koukios, 1987; GSE,2012; Ferrara et al., 2015).This development has taken place in terms of quantity, but not in terms of quality because, as appears from the 
Forest - Wood Plan 2012-2014 of Italian Ministry of Agriculture, the forest expansion phenomenon is mainly from a spontaneous recolonisation of abandoned farmland and pastures areas. These areas suffer from a lack of management or investment which limits their use and productivity. In fact, the national harvesting intensity in the last decade, near to 8 million $\mathrm{m}^{3}$ per year (GSE, 2012), is $25 \%$ per annum growth (estimated at 36 million $\mathrm{m} 3$ / year), compared to $65 \%$ of the average European. Harvested annual yields of wood in Italy $\left(2 \mathrm{~m}^{3} /\right.$ ha / year) amounted to half of those in France, Spain and Portugal ( $4 \mathrm{~m}^{3} /$ ha / year) and were considerably lower than in Germany and the UK (5.6 and $5.4 \mathrm{~m}^{3} /$ ha/year) (GSE, 2012).

This criticism is also accompanied by a political anachronistic concept that forest resources are only an economical - environmental reserve to be preserved rather than to be exploited properly, even for production, according to the concept of "sustainable forest management" (Di Mario et al., 2012).Furthermore, the current regulatory environment, born in 1923 to address conservation and protection issues for forests, has not been adequately updated to current and real needs of the area, both in environmental and economic terms. This results in a situation in which Italy continues to bear the high cost of hydrogeological instability, due to forests negligence and, at the same time, of massive imports, instead of using domestic resources.As a result it is appropriate to enhance the wood resource harvesting from forests according to national criteria that respect the environmental balance, and also create opportunities for economic development.

An interesting estimate of the biomass potential for energy use that could result from full exploitation of Italian forests, was created by Itabia in a study commissioned by the Italian Ministry of Agriculture "Document Preparatory to the National Plan Biofuels and Biomass agroforestry for energy purposes".In the absence of accurate data, this study produced estimates using the integration of information provided by IFNC (National Inventory of Forests and Forest Reservoirs Carbon) for 2005 with the most recent ISTAT about the uses and harvesting of wood.

The study funded by the Italian Ministry of Agriculture under the Project Biomass ENAMA has treated in detail the issue of energy recovery of residual biomass from the primary sector, focusing on the types, quality and technically suitability. The "strengths" of this resource reside mainly in the chemical-physical characteristics, in its consistency in quantitative terms, in the almost ubiquitous distribution and, finally, in the fact that their use for energy production doesn't affect the land area intended for use in food from which it derives (Pignatelliet al., 2014). As is well known, at a world scale, the fear of a conflict between food versus energy has created controversy in recent years overthe effects on the cost of food, especially in economically weak countries. Fortunately these problems have not had much effect in Italy thanks to their environmental policies especially for those concerning the green energy (Buchhlozet al., 2009, Zambelliet al., 2012, Perpinaet al., 2013).

Another limiting factor for start-up of an energy district are costs for harvesting and transport of biomass from agricultural fields (straw and twigs) and forests (wood waste) to the power plant.For these reasons acquisition of the road network and harvesting network into a geo-referenced database, can play a fundamental role in the decision making process for identifying the best location in terms of costs and of environment impact of the power plant in the analyzed territory.

Another consideration isdeveloping recoverytechniques forbiomass without reducingthe production of the agricultural systems. Some Italian regions recently performed tests on recovery techniques to be adopted in different farm contexts, combined with a high level of mechanization, which have 
contributed to efficient models that are emerging and spreading. For these reasons nowadays more and more farms are strongly motivated towards multi-functionality in terms of management and green energy policies.From an environmental perspective, it is useful to consider the current use of the residues before evaluating the benefits of energy use. Residues of tree crops are currently only partly recovered for firewood use, while mostly are shredded and buried on the spot or, in some cases, removed from cultivation and burned to prevent the possible spread of pathogens (Pignatelliet al., 2014). The residues of field crops instead provide an important contribution of organic matter to the soil in certain cases and so their removal can be a critical agronomic element and perhaps even climatic effect by storing organic carbon in the soil (Zoellneret al., 2008). Therefore, their possible use for energy purposes must be reviewed from time to time, giving priority to those methods of use which are able to ensure environmental benefits.

Under the new EU Agricultural Policy and, in particular, the Rural Development Programs, it is necessary to define a strategy on a national scale to support investments in agro-energy, energy efficiency and green chemistry by farmers. For example, it would be desirable to enhance the agroforestry national resource,currently about 11 million hectares, most of which are in a state of neglect, as well as marginal lands, which constitute a further possible opportunity for dedicated agroenergy development.

Biomass production should not create conflicts with agricultural production and therefore should be encouraged through cultural protocols with biomass integration, involving rotations benefitting traditional plantingsfor food, feed orfiber (Zambelli et al., 2012). In addition, large quantities of resources could and should result from proper forest management, which is also needed to counter the frequent disasters produced by fires and hydrogeological instability (Di Mario et al., 2012, Pignatelliet al., 2014).

For this reasonforest harvesting must be programmed in such a way as to ensure a consistent production over time. To achieve this, all the state forests located in the study area and currently managed at municipality level will in future be managed with the single aim of producing a steady supply of biomass.

Residual biomass is an important share (both quantitatively and qualitatively) of available resource within the bio-energy chain. Therefore, greater attention is needed to facilitate the sustainable use of waste and by-products, drawing a clear line between biomass and waste through the enactment of clear national standards and their application in different regions (Panichelliet al., 2008).

Therefore, the biomass production for energy must look primarily, in an Italian context, to the recycling and enhancement of waste, crop residues and processing of food products residues. The use of by-products and residues from agriculture, forestry and agro-industrial must be always evaluated with care to avoid an excessive removal of organic matter, with negative effects on agricultural and / or natural ecosystems. In particular, the risk of possible alterations in the cycle of the organic matter must be avoided, which would result in a damage to the quality of the soil, with losses of humus and residual fertility and with a rapid contraction of the potential production of any type of biomass (Uuemaaet al., 2013; Sang et al., 2013).

In contrast, in the case of residues resulting from ordinary forest maintenance, maintenance of river channels, etc. their removal and energy reuse is considered an effective solution in the prevention of 
other negative phenomena such as fires, uncontrolled water runoff, terrain erosion, etc (Kanzianet al., 2013).

The National Energy Strategy (NES) of March 2013, identifies three critical issues, four goals and seven priorities that characterize the Italian energy sector and act as reference points for its future development and strengthening in pursuit of greater economic and environmental sustainability. In particular, the NES priorities to be implemented by 2020 are:

- Energy efficiency;

- A competitive market for gas and a south European hub;

- Sustainable development of renewable energy;

- Infrastructure development and the Electricity Market;

- Restructuring of the refining and fuel distribution network;

- Sustainable national production of hydrocarbons;

- Modernization of the system of governance.

In this context, the development of biomass energy industry presents many relevant points and overall the potential to contribute significantly tosupporting agriculture and the environment in general, especially in rural areas.

In order to revitalize the role of agriculture as a key element for the achievement of National and Community targets on renewable energy, due to the specific and particular characteristics of the agro-energy compared to other kinds of renewable sources, it is necessary to ensure an effective coordination among all institutional actors involved and the different means of action adopted. Bioenergy crosses a multiplicity of themes and sectors whose responsibilities involve several departments at central and local levels as many departments. The shortage, and in some cases the total absence of a balanced synergy between these administrations limits the effectiveness, strength and timeliness of governance at the expense of the national system. The improvement of existing mechanisms for consultation will guide the development of the sector allowing consistent measures to be taken on issues through shared competence.

\section{Objectives of our study}

Many conferences, summits and protocols, developed at European level, have pointed out that there is a great interest in implementing policies to reduce the climate change impact on environmental quality, through improving energy efficiency and development of renewable sources. This has increased the willingness to develop a green economy, which is not only an environmental improvement, but also a new paradigm to alleviate global threats such as climate change, biodiversity loss, desertification, depletion of natural resources and, at the same time, promote social and economic welfare (Scott et al., 2012; Sacchelliet al., 2013).

Issues related to climate change have led to a greater importance of heat and power production based on the use of renewable sources. 
In Italy, use of alternative energy resources could be a valuable contribution to reduce the dependence of national energy system on imports. In particular, the agro-forestry biomass sector is one of the major areas of possible implementation of bioenergy, due to rurality and a strong link between the agricultural and forestry sectors in large national areas (Sacchelliet al., 2013).

This context underlines the need for interaction between urban, land and energy planning, because most energy consumption and production depends not only on socioeconomic variables, but also on territorial organization. It is therefore important to define spatial planning that leads to energy efficiency. The inter-sectoral approach that is developed in our study makes use of multi-criteria analysis (MCA), which can aggregate variables identified by different units, as well those of mixed types (such as qualitative and quantitative data); it can be a good tool to use in the planning processes (Buchholz et al., 2009, Recchia et al., 2010, Sang et al., 2013).

In this context, this paper aims to provide a valuable model to estimate the agro-forestry biomass availability for energy use, based on a thorough analysis ata local scale, in an agro-environmental context characterized mainly by agricultural and forestry land use, also representative of a rural areathat is typical of many national and international areas, especially in the Mediterranean.

In the identification of an energydistrict in rural areas, this work underlines the lack of tools suitable for decision-making and planning at a wider scale. Also, the particular value of an environment (presence of important natural sites), forces planners to usean interdisciplinary approach to choose the most appropriate analysis and evaluation method. Indeed, the presence of such sites, which are very common across Europe, increases the importance ofidentifying an appropriate land use for energy planning while, at the same time, protecting the natural valueof the area, according to European environmental legislation.

The identification of an effective planning methodology represents the main goal of the present research, whose applicability can be extended within the European community.

One of the main limiting factors in land use planning consists of alack of georeferenced databases and even when existing they appear fragmented in their spatial and temporal scale.

There is also a lack of adequate legislation on the sustainable management of processing agroforestry waste. Currently, for example, trees pruning in wood industry, are mainly burnt in the field (Pignatelliet al., 2014), while the waste from agricultural processing is only partially reused in the farms and the rest is treated as waste. In forestry it is difficult to find the correct information, because you do not always have access to the management plans of all the forests in the area (Kinoshita et al., 2009).

Through this work we intend, therefore, to create a model to estimate the potential value of agroforestry biomass from different agricultural sectors. For this aim we used a Multi Criteria Analysis, developed in a GIS environment to analyze territorial, economic, social and planning variables. This model combines an innovative analysis approach at both agricultural and forestry level, to estimate the biomass available and its distribution in the territory. It is waste biomass and for this reason it doesn't constitute a source of competition for the other economic sectors, nor should it affect levels of system integrity and the future resource. This model is a response to the needs of energy 
planning, that is lacking with the current tools available, and that allows for a preliminary energy estimate for the correct sizing of a power plant and the subsequent correct placement of the same.

\section{Materials and methods}

\section{The study area}

Tuscia Romana,located incentral Italy, includes 12 municipalities of the northern Lazio region. This area has a total surface of $720,5 \mathrm{~km}^{2}$ andis located halfway between the cities of Rome and Viterbo. The area is characterized by an average surface per municipality of $60.26 \mathrm{~km}^{2}$, with an average population of 6548 inhabitants per municipality (ISTAT, 2010). The average altitude is $357.25 \mathrm{~m}$ above sea level, so from the phytoclimatic point of view the area is between Lauretumand Castanetum bands, characterized by average annual temperatures between $13^{\circ} \mathrm{C}$ and $1{ }^{\circ} \mathrm{C}$ and average annual rainfall of $900 \mathrm{~mm}$, with a summer water deficit. In the area there are numerous protected areas: parks, SCI (Sites of Community Importance) and SPA (Special Protection Areas). The area therefore has a natural vocation for agriculture and forestry. Figure 1 shows the municipalities within Tuscia Romana, while figure 2 includes the main points of natural interest. For orographic characteristics, climatic conditions and for its land use this area can be considered veryrepresentative of central Italy. Furthermore, this area has been recently selected by B.I.C.(Business and Innovation Centre) Lazio, an agency aimed in valorizing the regional territory, as a pilot project in renewable energy.

\subsection{The data set}

We have used the following as reference data:

Forestry assessment plans for all state-owned forests of the agro-energetic district (B.I.C. Lazio, 2013). For all the municipalities included in the study area we acquired the plans for state forestry management for the implementation of the GIS database. Dendrological and silvicultural parameters such as: surface area of the forest, tree density, age, species and year of harvesting were georeferenced and analyzed to investigate the potential of each forest toproduce waste biomass for energy production;

Land Use Map (1:25.000). The layer describing the usage of the soil classified according to Corine Land Cover (CLC) Project of the European Community;

Road network. Vector files of the asphalt roads and of the forest harvesting tracks have been acquired for this study. Through remote sensing of georeferenced digital aerial photographs, taken in 2012, all the asphalted roads and the forest harvesting tracks have been photo-interpreted at a scale of 1:5000.

Before using the data for multi criteria analysis we have evaluated these data to identify the biomass availability for energy use (Mendoza et al., 2000).

For the forestry district sector we have combined the Corine Land Cover data with the B.I.C. Lazio data. This is because the CLC data was not very detailed. For each municipality we have considered total resource $\left(\mathrm{m}^{3}\right)$; we have calculated the biomass available for energy use $\left(\mathrm{m}^{3}\right)$ as $18 \%$ of the total resource, in accordance with the method reported by Hellrigl (Hellrigl, 2004;Kinoshita et al . 2009; Colantoni et al., 2013; Sacchelliet al., 2013; Colantoni et al., 2015). Finally, using the net calorific value (assuming a water content of $33 \%$ ) we have obtained the energy availability in terms of 
$\mathrm{kWh}_{\text {th }}$ (Tab. 1). These are calculated for each year from 2010 to 2045. In figure 3 we have shown graphically the total availability, obtained by adding the values for each municipality, for both "biomass energy" and "kWh $\mathrm{th}_{\mathrm{th}}$. The trend is modeled as a decreasing polynomial.

It is clear that the availability of biomass has a peak that coincides with the five-year period 20152020; after this it decreases progressively until the five-year period 2040-2045. From this the need for having other biomass sources to feed a hypothetical plant is clear. For this reason agro - forestry biomass is also considered(herbaceous and agro-forestry crops).

For the agricultural sector we have combined the Corine Land Cover data (fig. 4) (Regione Lazio, 2000).

Forthis purpose we have considered only the following CLC land use classes:

- green urban areas;

- land mainly occupied by agriculture, with significant areas of natural vegetation;

- annual crops associated with permanent crops;

- non-irrigated arable land;

- permanently irrigated land;

- surfaces with dense herbaceous cover;

For agro-forestry crops we have considered the following classes:

- fruit trees;

- vineyard;

- olive groves.

We have restricted the land uses to those that are the most significant for this search.

For each of these crops we have calculated (Delfantiet al., 2014) the total quantity (t) of dry matter; from this we have estimated the percentage available for energy use, as $50 \%$ for the herbaceous biomass and $100 \%$ for agro forestry crops. This is in accord with the table 2 reworked from data of Enama (ENAMA, 2008).

Finally, using the calorific value (Hellrigl, 2004; ENAMA, 2008) we have obtained the available heat in terms of $\mathrm{kWh}_{\mathrm{th}}$. The results are reported in table 3 .

We have gridded this data to create raster files in IDRISI (G.I.S. software) to perform multi criteria analysis.

This multi criteria analysis has been performed to obtain the biomass availability (Phuaet al., 2005; Buchholz et al., 2009; Recchia et al., 2010) in the twelve municipalities of Tuscia Romana.

We have included nine spatial variables that the software has related and compared, combining scales and multidimensional measurements in a single scale of priorities. The variables, in order of priority, are:

Slope: this layer represents the study area zoned into slope classes. This grid file is calculated from a D.E.M. (Digital Elevation Model) of Lazio Region with a resolution of $20 \mathrm{~m}$. Slope is very important in this analysis because it represents a limiting factor in biomass harvesting: forestry and agricultural mechanical work is only possible with slopes of less than 30\% (Barbatiet al., 2012);

Areas of municipals forests: total area of state-owned forests detected at patch scale; 
Agricultural and Forestry systems: this layer is very important in detecting the quantity of biomass that is truly available using the existing infrastructure network.To do this it is necessary to analyze the accessibility of the harvested area (forest tracks and asphalt roads).

Distance from the forest tracks: layer representing distance from the nearest forest track.

Distance from asphalt roads: layer representing distance $(\mathrm{m})$ from the asphalt roads for the whole municipal territory.

Accessibility (via forest tracks and asphalt roads) is the most important factor because it allows transport of the biomass to the plant. The closer the forest is to the road and the plant, the less it will cost in terms of transport and pollution (Allen et al., 2011).

Forest species: state-owned forests (8950 ha) are classified according to the calorific value of each species. The forestry areas are represented by four principal species: Quercuscerris L. (broadleaf oak), Castanea sativa Miller (sweet chestnut), Pinusspp. (Pines, including Pinuspinea L., Pinus pilaster Aiton, PinusJ.F.Arnold), Fagus sylvatica L. (European beech). The calorific value (Hellrigl, $2004)$ is calculated from their relative availability.

Road network: layer in which the whole territory analyzed is classified according to the distance by asphalt roads.

Distance from municipal forests: study area classified according to distance from the municipal forest.

The georeferenced data set has been employed in a Multi Criteria Analysis performed in GIS environment according to fuzzy analysis. Every layer has been processed to better interpret the realistic potential of the system to produce biomass.

\section{Results}

Figure 4 shows the results obtained by the multi criteria analysis performed according to fuzzy logic. The whole territory has been zoned in a scale of values that ranges from 1 to 199: values of 1 indicate areas with a low potential; those with 199, are perfect to provide biomass.Analyzing the spatial distribution on the territory, regarding the suitability in producing biomass we found a very good capacity in terms of biomass availability to support an agro energy chain for Tuscia Romana district.

Despite the study area beingcharacterized by a hilly environment and a high density of human settlement (urban sprawl), more than $45 \%(324 \mathrm{Km} 2)$ of the whole area possessessuitable characteristics to produce and to harvest biomass for energy plants. This result is due to two main factors: a good capacity forproducing biomass inthe agroforestry system and a high density of roads that makes collection and transport to the plantpossible.Due to the high density of human settlements the road network follows a homogeneous distribution overthe territory making for efficient production and harvesting of biomass for energyuse. The presence of forest roads especially in those more productive forests, allows harvesting of a large quantity of biomass with a high calorific.A limiting factor identified isthe absence of aligned planning among the municipalities of Tuscia Romana concerning the management of forests.

Unlike agricultural environments where croprotation is scheduled each year, for forest cultivations harvest times for different species depend on several factors such as: trees species; age; silvicultural management and the duration, in years, of the harvesting cycle. 
Forall municipalities of Tuscia Romana, the predicted availabilityof biomass, figure 3, is not homogeneous, with excess production in the short term and shortage after 2025. This requiresfuture management to organize the use of the forests in such a way as to havea constant production over the time. Therefore, all municipalities must coordinatethe management of their forest land in accordance with the other municipalities of Tuscia Romana.

As regards the identification of areas most suitable for the sitingof an energy plant, the availability of very detailed data for the territory hasallowed the identification of two areas within the Tuscia Romana, each of which exceeds two hectares.In this case the main parameter considered has been distance from roads. From an environmental and economic point of view, the optimumdistance within which to supply of biomass is within $20 \mathrm{Km}$ (Fig. 6).

\section{Discussion and Conclusion}

In conclusion, Multi Criteria Analysis (MCA), performed using fuzzy logic, represents a powerful tool for investigating the potential of the territory for biomass production.Most of the area has a useful amount of biomass that can be used for energy purposes (area in figure 5 scoring over 100). This amount of biomass could be increased by includingthe private forests in the energydistrict. At the current state ofthis research we have only considered the state-owned forests because their future common management from an energy point of view is more realistic - private owners may not agree with this kind of policy because in this case the management of the forest is often more expensive.

One of the key limiting factors in the methodology proposed is represented by the difficulty in collecting data especially for forestry production. In the study of an agro-energy production chain knowledge of the territory is important as it strongly influences the biomass availability.Knowledge of the area depends on the quality of the starting data. For this reason the Corine Land Cover data was combined with the B.I.C. Lazio data, in particular for forestry data.

Another important aspect in defining the real capability of the agro forestry system to providebiomass for an energy plant, consists ofplanning and compiling a georeferenced database able to detect the complexity of the environments systems. Data such as the road network, forest tracks and dendrological and silvicultural parameters are often difficult to find and require time-consuming data acquisition forthe GIS database.

The optimum location of an agro-energy production chain facility, the type of plant and environmental feasibility of this (e.g. using a L.C.A. - Life Cycle Assessment approach) can be determined on the basis of the data obtained from the analysis carried out in this study. 


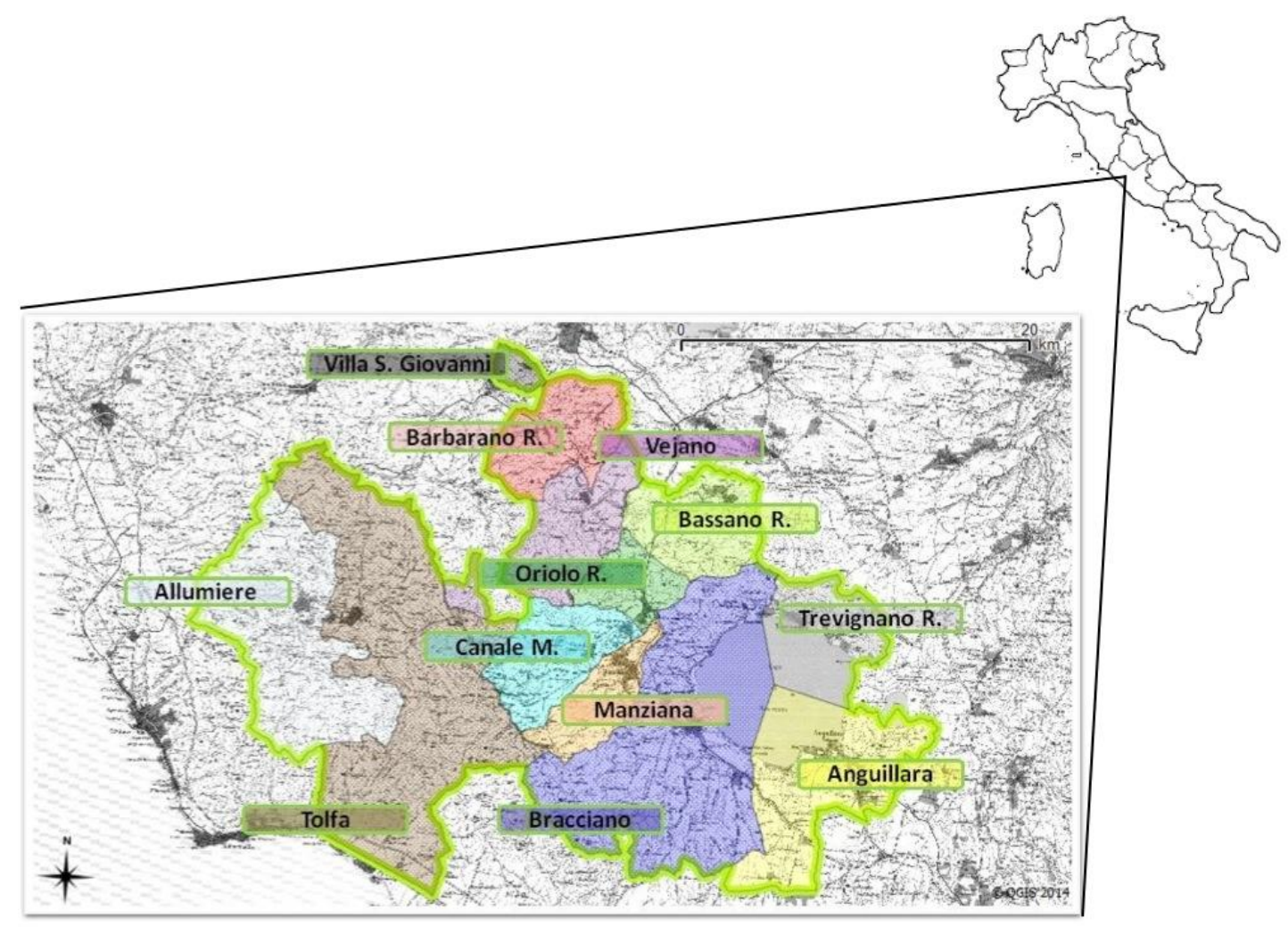

Figure 1: location of the studied area. Tuscia Romana (central Italy). 


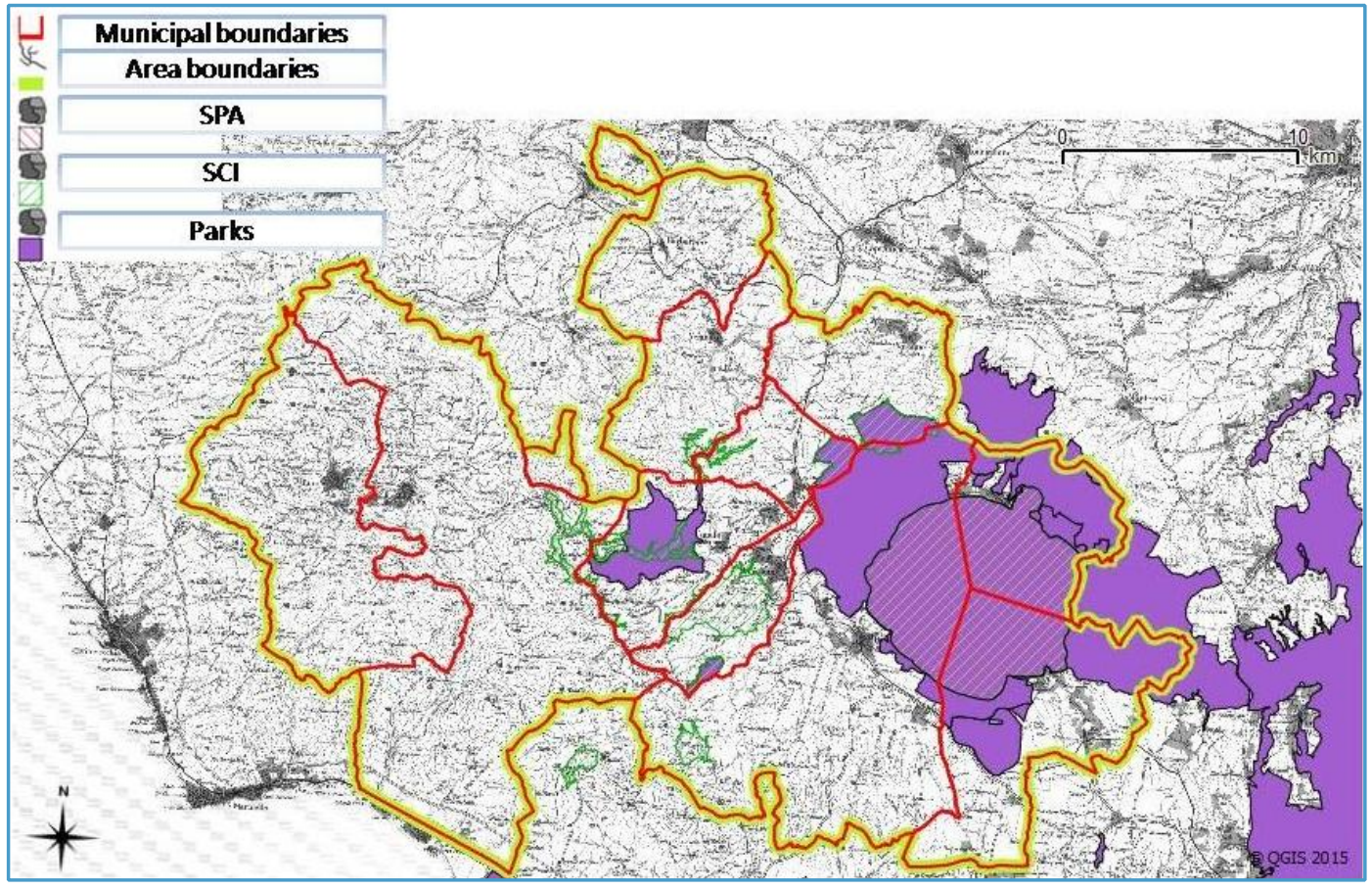

Figure 2: location of protected areas (SPA, SCI, Parks).

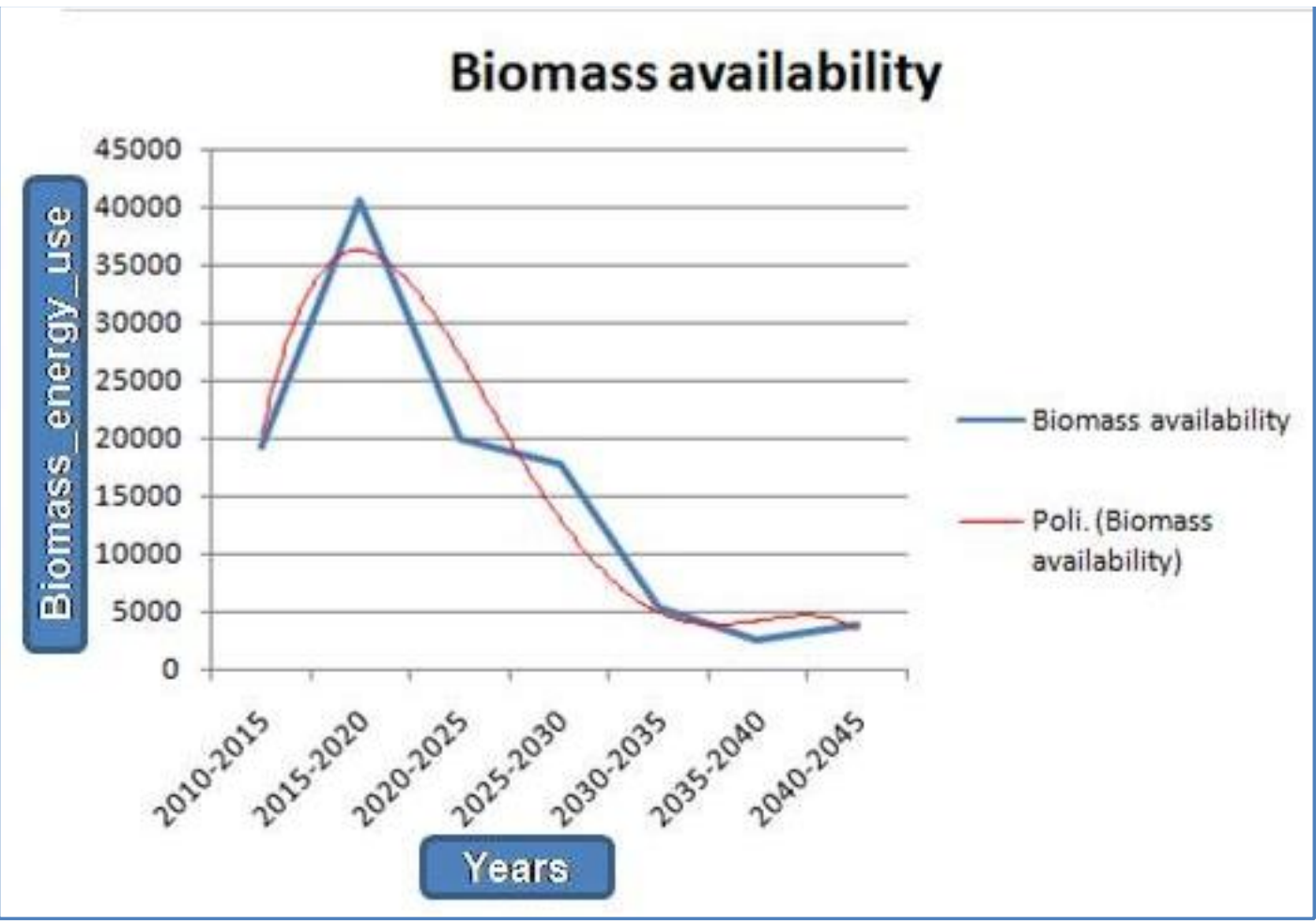

Figure3: the availability of biomass for energy use in future years, also represented as polynomial function (Poli). 


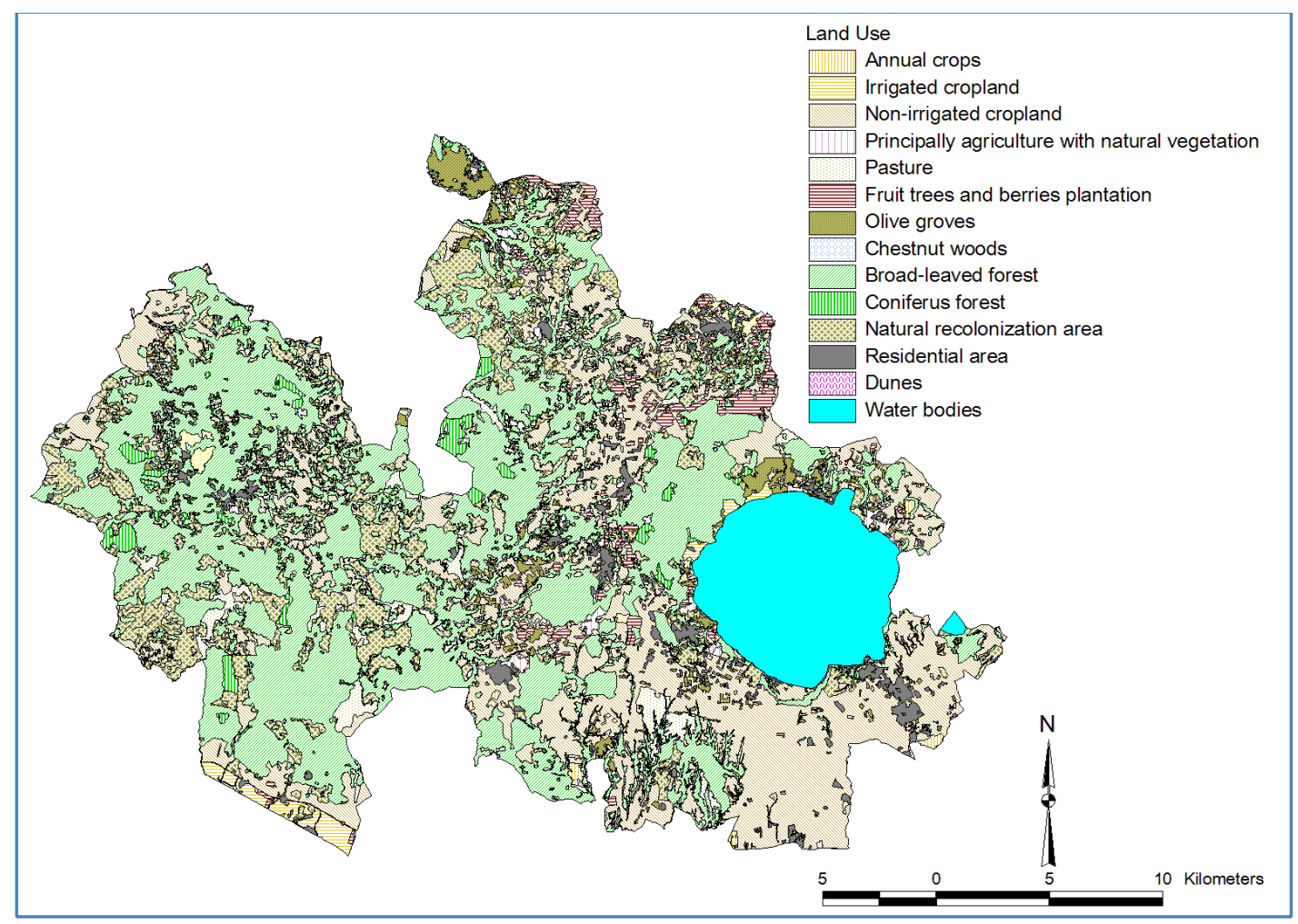

Figure 4: Land Use Map - Corine Land Cover (Regione Lazio, 2000).

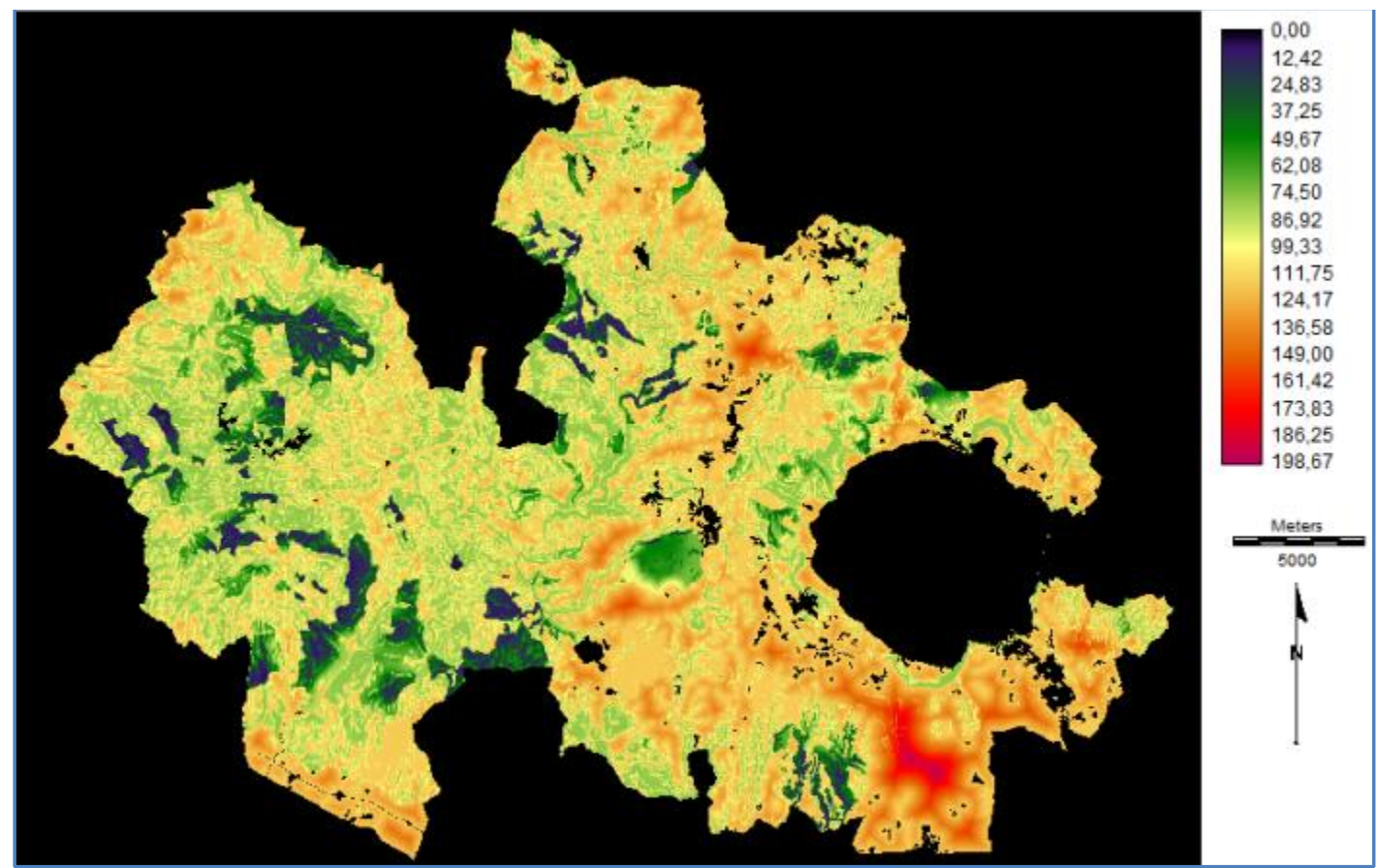

Figure 5: Multi Criteria Analysis: suitability of analyzed territory for biomass production. 


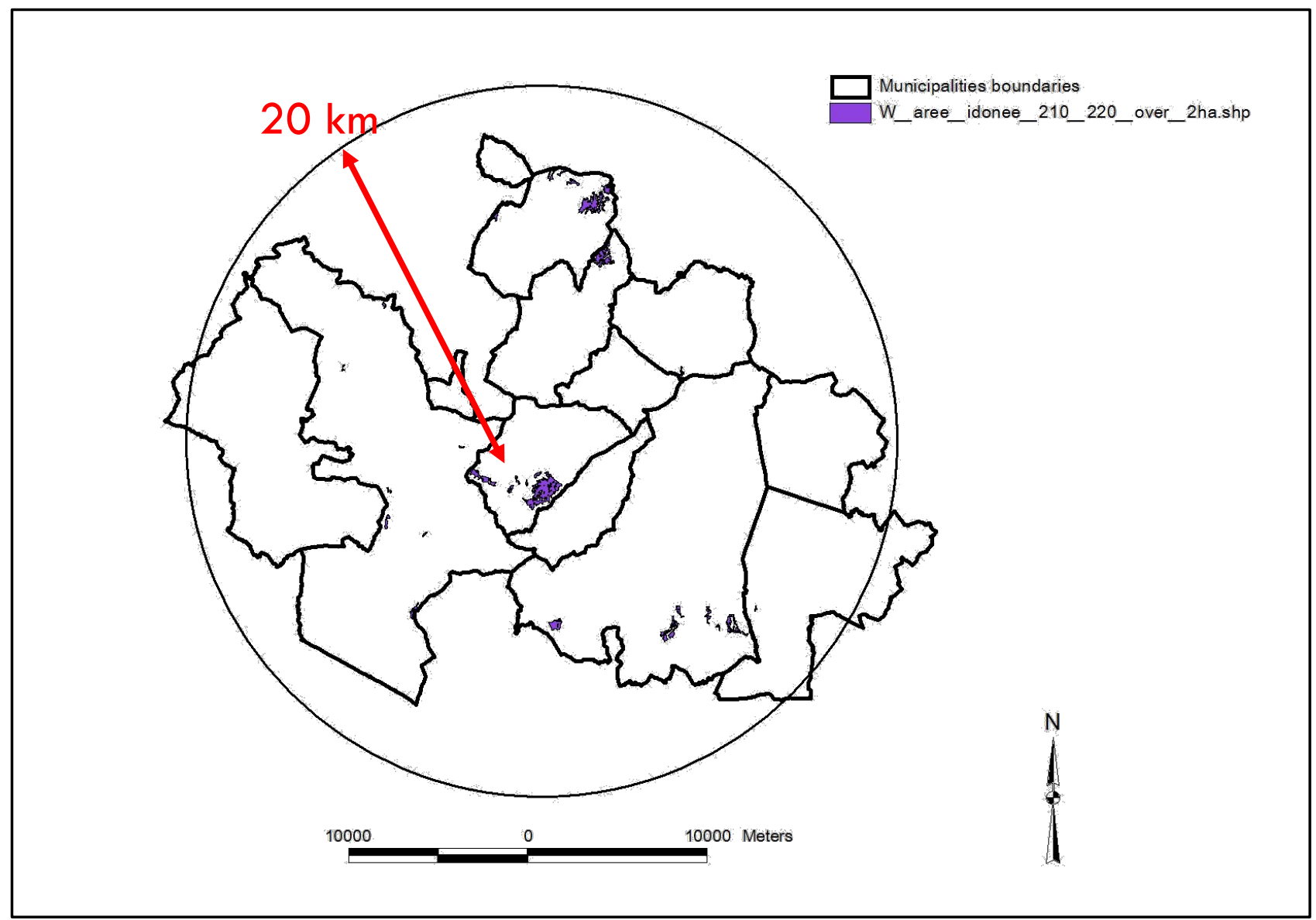

Figure 6. Locations in the agroforestry energydistrict of areas suitable for biomass plants. 


\section{References}

Allen, J., Browne, M., Hunter, A., Boyd, J., Palmer, H., 1998. Logistics management and costs of biomass fuel supply. International Journal of Physical Distribution \&Logistics Management, 28, 463-477.

Barbati, A., Corona, P., Mattioli, W., Quatrini, A., 2012. Biomassa forestale per la produzione di energia termica: un modello di analisi per l'alta valle dell'Aniene. Italian Journal of Forest and Mountain Environments, 67 (4), 329-336.

Bentsen, N.S., Felby, C., 2012. Biomass for energy in the European union-a review of bioenergy resource assessments. BiotechnolBiofuels, 5 (1), 1-10.

BIC Lazio, 2013. Piani di gestione dei boschi demaniali del Lazio. Rapporto 2013.

Bilgili, F., Ozturk, I. 2015. Biomass energy and economic growth nexus in G7 countries: Evidence from dynamic panel data. Renewable and Sustainable Energy Reviews,49, 132-138

Blumentrath, C., SundliTveit, M., 2014. Visual characteristics of roads: a literature review of people's perception and Norwegian design practice. Transportation Research Part A, 59, 58-71.

Buchholz, T., Rametsteiner, E., Volk, T. A., Luzadis, V. A., 2009. Multi Criteria Analysis for bioenergy Systems assessments. Energy Policy, 37, 484-495.

Colantoni, A., Mavrakis, A., Sorgi, T., Salvati L., 2015. Towards a 'polycentric' landscape? Reconnecting fragments into an integrated network of coastal forests in Rome. Rendiconti Lincei, 1-10.

Colantoni, A., Recanatesi, F., Baldini, S., Felicetti, M., Romagnoli, M., 2013. Decision analysis for the determination of biomass in the territory of Tuscia Romana by geographic information system and forest management plans. Journal of Agricultural Engineering, 44 (s2) 16-18.

DecretoMinisteriale n. 9800 del 27 aprile 2012. Tavolo di Filiera per le Bioenergie. Biomasse biocarburanti e bioliquidi - biogas e biometano - chimica verde. Stato dell'arte della bioenergia in Italia. 2014.

Delfanti, L. M. P., Bedini, R., Romagnoli, M., Recanatesi, F., Meacci, F., Caruso, L., Manzo, A., Salvati, L., 2014. Estimation of Agroforestry biomasses available for energy purposes in a municipality in central Italy as instrument for energy planning. Applied Mathematical Sciences, vol. 8 (131), 6577-6587.

Di Mario, F., Braccio, G., Pignatelli, V., Colonna, N., Zimbardi, F., 2012. Quaderno - Biomasse e Bioenergia. ENEA (Agenzia nazionale per le nuove tecnologie, l'energia e lo sviluppo economico sostenibile).

Enama, 2008. Biomasse ed energia. Caratteristiche tecniche delle biomasse e dei combustibili. Progettobiomasse.

European Council. Directive 2009/28/EC of the European Parliament and of the council. On the promotion of the use of energy from renewable sources and amending and subsequently repealing Directives 2001/77/EC and 2003/30/EC, Official J Eur Union L140/16, Brussels.

Ferrara, C., Barone, P.M., Salvati, L., 2015. Towards a socioeconomic profile for areas vulnerable to soil compaction? A case study in a Mediterranean country. Geoderma, 247-248, 97-107. 
GSE (Gestore Servizi Energetici). Rapporto statistico 2012. Impianti a fonti rinnovabili - Settore elettrico.

Hall, D. O., House, J. I. 1995. Biomass energy in Western Europe to 2025. Land Use Policy, 12(1) $37-48$

Helrigl, B., 2004. Il potere calorifico del legno. Convegno studio "Le biomasse agricole e forestali nello scenario energetico nazionale". ProgettoFuoco 2004, Verona 18-19 marzo 2004.

Hummel, F. C. 1988. Biomass forestry: implication for land use policy in Europe. Land Use Policy, 5(4) $375-384$

ISTAT, 2012. La progettazione dei censimenti generali 2010 -2011. Informazione e formazione ai comuni sulle innovazioni di metodi e tecniche per il $15^{\circ} \mathrm{Censimento} \mathrm{generale} \mathrm{della} \mathrm{popolazione} \mathrm{e}$ delle abitazioni. (1) 6-93

Jiao, L., Mao, L., Liu, Y., 2015. Multi-order landscape expansion index: characterizing urban expansion dynamics. Landscape and Urban Planning, 137, 30-39.

Kanzian, C., Kuhmaier, M., Zazgornik, J., Stampfer, K., 2013. Design of forest energy networks using multi-objective optimization. Biomass and bioenergy, 58, 294-302.

Kinoshita, T., Inoue, K., Iwao, K., Kagemoto, H., Yamagata, Y., 2009. A spatial evaluation of forest biomass usage using GIS. Applied Energy, 86, 1-8.

Koukios, E. G. 1987. The effects of new biosystems technology on land use: The case of the European Community. Land Use Policy, 4(3) 219-228.

Mendoza, G. A., Prabhu, R., 2000. Multiple criteria decision making approaches to assessing forest sustainability using criteria and indicatos: a case study.Forestecology and management, 131, $107-$ 126.

Perpina, C., Martinez-Llario, J. C., Perez-Navarro, A., 2013. Multicriteria assessment in GIS environments for siting biomass plants. Land Use Policy, 31, 326-335.

Phua, M., Minowa, M., 2005. A GIS-based multi-criteria decision making approach to forest conservation planning at a landscape scale: a case study in the Kinabalu Area, Sabah, Malaysia. Landscape and Urban Planning,71, 207-222.

Recanatesi, F., Tolli, M., Lord, R. 2014. Multi criteria analysis to evaluate the best location of plants for renewable energy by forest biomass: A case study in central Italy. Applied Mathematical Sciences, 8 (129-132), pp. 6577-6587

Recchia, L., Cini, E., Corsi, S., 2010. Multicriteria analysis to evaluate the energetic reuse of riparian vegetation. Applied Energy, 87, 310-319.

Regione Lazio, 2000. Carta di Uso del Suolo. Tavola 19, Foglio 364 - Inquadramento ED50.

Sacchelli, S., De Meo, I., Paletto, A., 2013. Bioenergy production and forest multifunctionality: A trade-off analysis using multi scale GIS madel in a case study in Italy. Applied Energy, 104, 10-20.

Salvati, L., Ferrara, C., Corona, P., 2015. Indirect validation of the Environmental Sensitive Area Index using soil degradation indicators: A country-scale approach. Ecological Indicators, 57, 360365 . 
Shaghaygh, A., Taraneh, S., Ken, D., 2014. Economic feasibility of utilizing forest biomass in district nenergy. Renewable and sustainable energy reviews, 33, 117-127.

Perpiña, C., Martínez-Llario, J.C., Pérez-Navarro, Á., 2013. Multicriteria assessment in GIS environments for siting biomass plants. Land Use Policy, 31, 326-335.

Panichelli, L., Gnansounou, E., 2008. GIS-based approach for difining bioenergy facilities location: a case study in northern Spain based on marginal delivery costs and resources competition between facilities. Biomass and Bioenergy, 32, 289-300.

Phua, M., Minowa, M., 2005. A GIS-based multi-criteria decision making approach to forest conservation planning at a landscape scale: a case study in the Kinabalu area, Sabah, Malaysia. Landscape and Urban Planning, 71, 207-222.

Pignatelli, V., Monni, M., Pari, L., Mannelli, S., 2014. Piano di settore per le bioenergie. Ministero delle Politiche Agricole Alimentari e Forestali.

Scott, J.A., Ho, W., Dey, P.K., 2012. A review of multi-criteria decision-making methods for bioenergy systems. Energy, 42, 146-156.

Sang, A.O., Tveit, M.S., 2013. Perceptions of stewardship in Norvwegian agricultural landscapes. Land Use Policy, 31, 557-564.

Shi, Y., Sun, X., Zhu, X., Li, Y., Mei, L., 2012. Characterizing growth types and analyzing growth density distribution in response to urban growth patterns in peri-urban areas of Linyungang city. Landscape and Urban Planning, 105, 425-433.

Uuemaa, E., Mander, U., Marja, R., 2013. Trends in the use of landscape spatial metrics as landscape indicators: a review. Ecological Indicators, 28, 100-106.

Yue, C., Yang, G. G., 2007. Decision support system for exploiting local renewable energy surces: A case study of the Chigu area of southwestern Taiwan. Energy Policy, 35, 383-394.

Zambelli, P., Lora, C., Spinelli, R., Tattoni, C., Vitti, A., Zatelli, P., Ciolli, M., 2012. A GIS decision support system for regional forest management to assess biomass availability for renewable energy production. Environmental Modelling \& Software, 38, 203-213.

Zoellner, J., Schweizer-Ries, P., Wemheuer, C., 2008. Public acceptance of renewable energies: results from case studies in Germany. Energy Policy, 36, 4136-4141. 
Table 1: Biomass destined to energy use for forestry district sector (total for whole municipality).

\begin{tabular}{ccc}
\hline Years & Biomass energy use $\left[\mathrm{m}^{3}\right]$ & $\mathrm{kWh}_{\text {th }}$ \\
\hline $2010-2015$ & 19300,4 & 57800231,1 \\
$2015-2020$ & 40486,2 & 119046129,3 \\
$2020-2025$ & 20031,5 & 122184048,2 \\
$2025-2030$ & 17668,4 & 51579775,8 \\
$2030-2035$ & 5342,9 & 15590228,1 \\
$2035-2040$ & 2626,3 & 7483889,8 \\
\hline
\end{tabular}

Table 2: Percent of reusable agricultural residues (Enama, 2008).

\begin{tabular}{ccc}
\hline Crop & Use & \% Used \\
\hline Triticum $L$. & Straw & 50 \\
\hline Hordeum $L$. & Straw & 50 \\
Avena $L$. & Straw & 50 \\
Zea. $L$. & Stalks & 50 \\
Vitis $L$. & Prunings & 100 \\
Olea $L$. & Wood & 100 \\
\hline Fruit-bearing & Branches & 100 \\
\hline
\end{tabular}

Table 3: results of biomass destined to energy use. The total is reported for annual crops and for permanent crops.

\begin{tabular}{lll}
\hline & Biomass energy use $[\mathrm{t}]$ & $\mathrm{kWh}_{\mathrm{th}}$ \\
\hline Annual crops for energy use & 87645 & 400723125 \\
Permanent crops for energy use & 10289,5 & 50941007,3 \\
\hline
\end{tabular}


Table 1: Biomass destined to energy use for forestry district sector (total for whole municipality).

\begin{tabular}{ccc}
\hline Years & Biomass energy use $\left[\mathrm{m}^{3}\right]$ & $\mathrm{kWh}_{\mathrm{th}}$ \\
\hline $2010-2015$ & 19300,4 & 57800231,1 \\
$2015-2020$ & 40486,2 & 119046129,3 \\
$2020-2025$ & 20031,5 & 122184048,2 \\
$2025-2030$ & 17668,4 & 51579775,8 \\
$2030-2035$ & 5342,9 & 15590228,1 \\
$2035-2040$ & 2626,3 & 7483889,8 \\
\hline
\end{tabular}

Table 2: Percent of reusable agricultural residues (Enama, 2008).

\begin{tabular}{ccc}
\hline Crop & Use & \% Used \\
\hline Triticum $L$. & Straw & 50 \\
Hordeum $L$. & Straw & 50 \\
Avena $L$. & Straw & 50 \\
Zea. $L$. & Stalks & 50 \\
Vitis $L$. & Prunings & 100 \\
Olea $L$. & Wood & 100 \\
Fruit-bearing & Branches & 100 \\
\hline
\end{tabular}

Table 3: results of biomass destined to energy use. The total is reported for annual crops and for permanent crops.

\begin{tabular}{llc}
\hline & Biomass energy use $[\mathrm{t}]$ & $\mathrm{kWh}_{\mathrm{th}}$ \\
\hline Annual crops for energy use & 87645 & 400723125 \\
\hline Permanent crops for energy use & 10289,5 & 50941007,3 \\
\hline
\end{tabular}




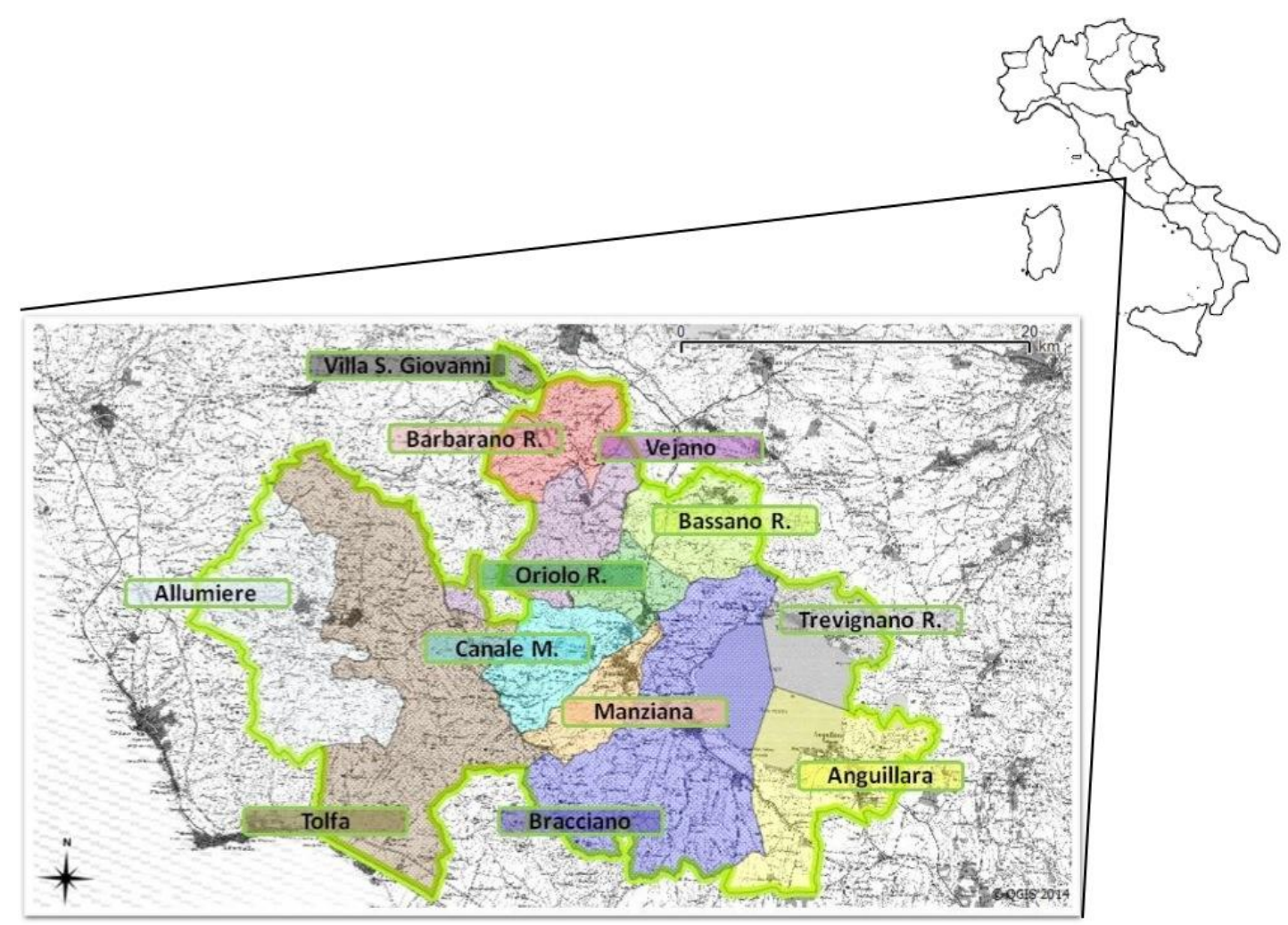

Figure 1: location of the studied area. Tuscia Romana (central Italy). 


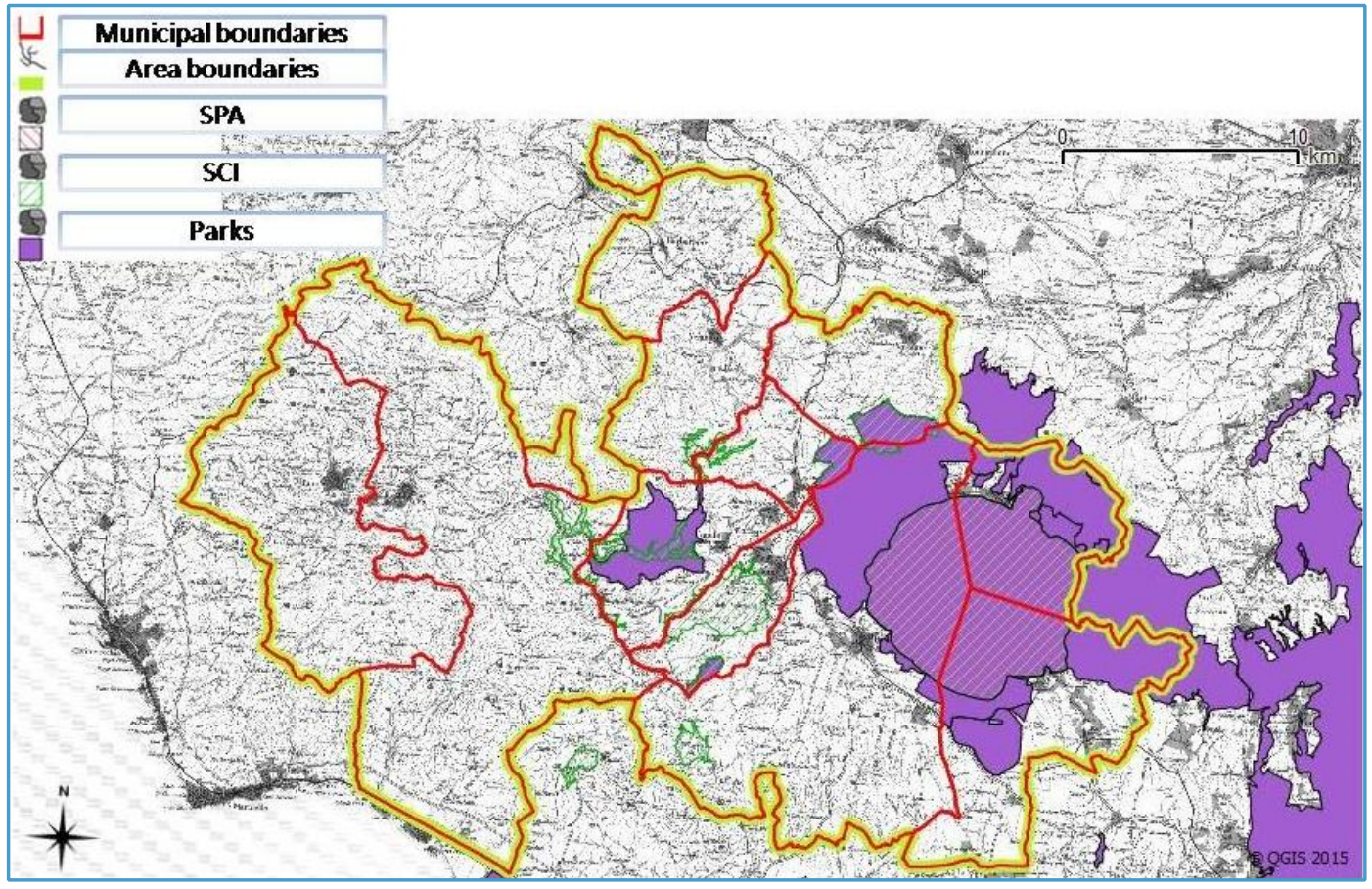

Figure 2: location of protected areas (SPA, SCI, Parks).

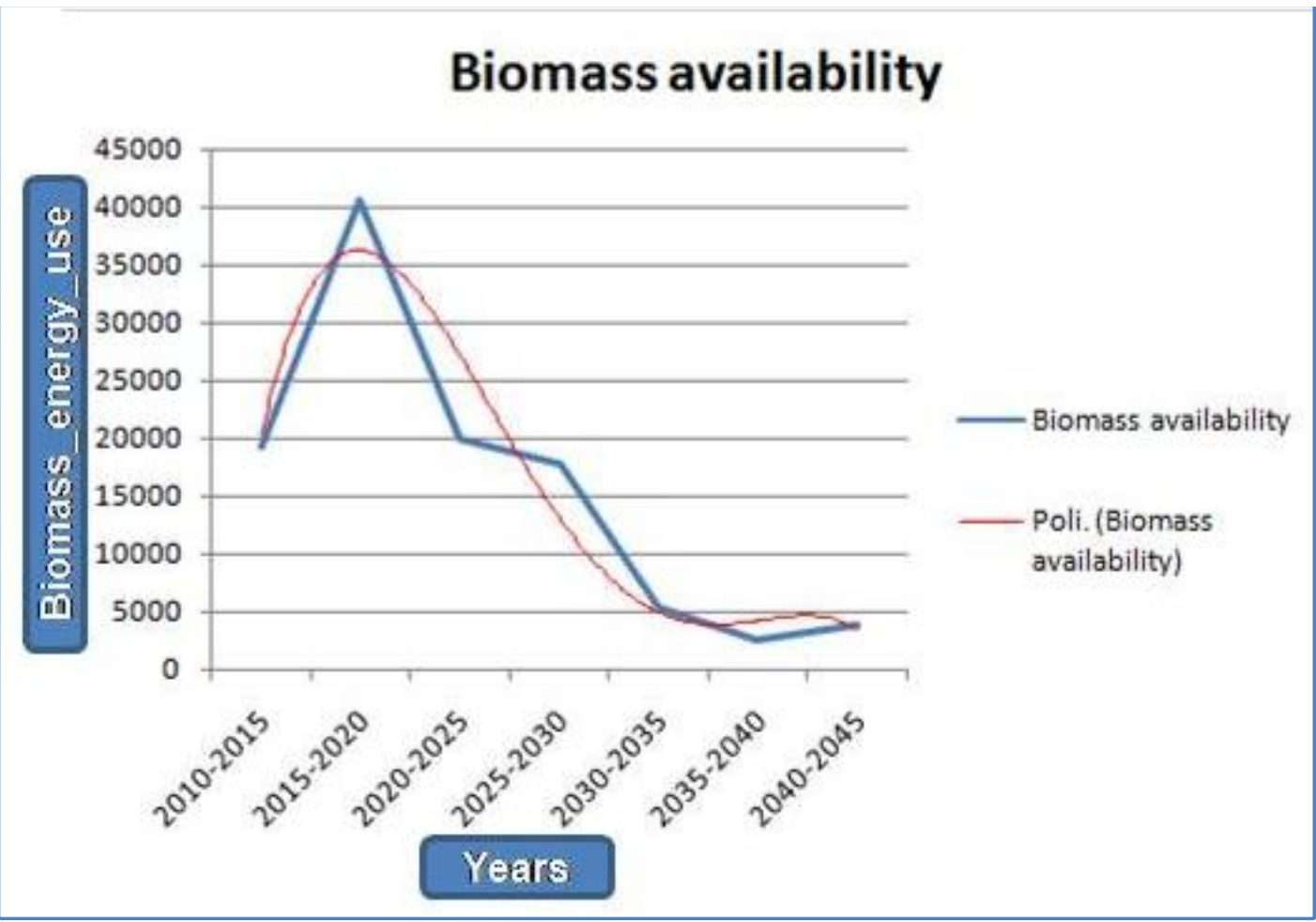

Figure3: the availability of biomass for energy use in future years, also represented as polynomial function (Poli). 


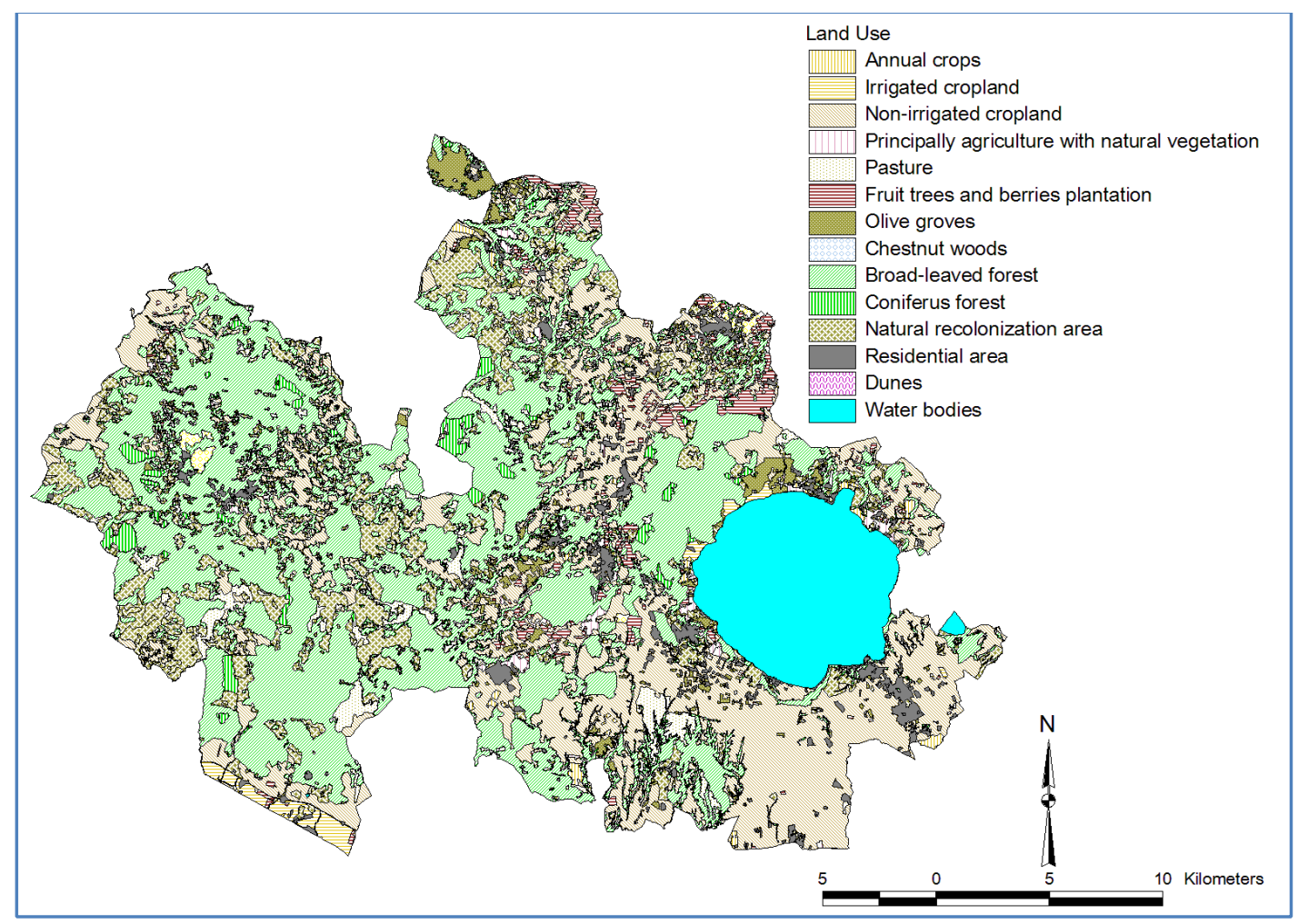

Figure 4: Land Use Map - Corine Land Cover (Regione Lazio, 2000).

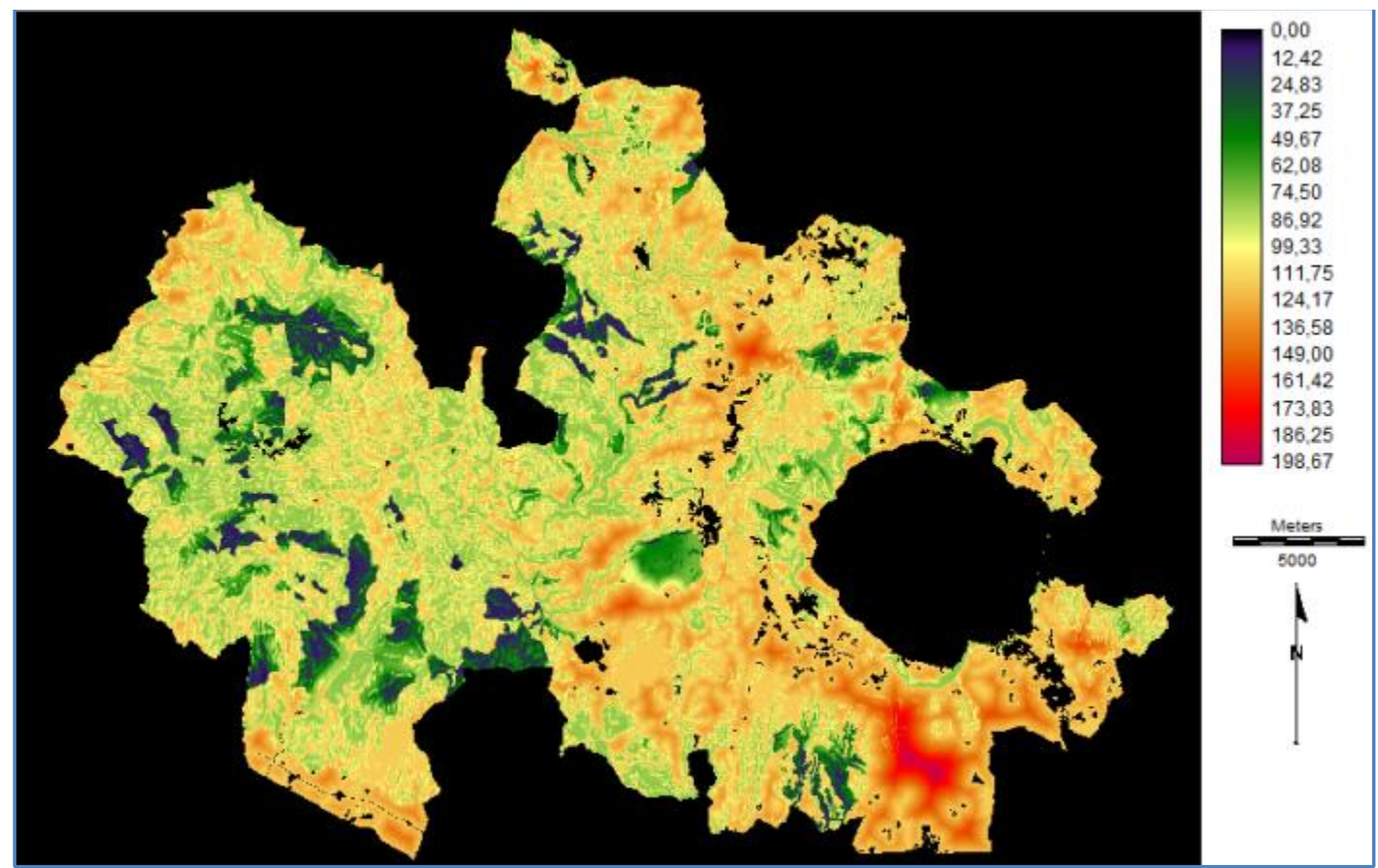

Figure 5: Multi Criteria Analysis: suitability of analyzed territory for biomass production. 


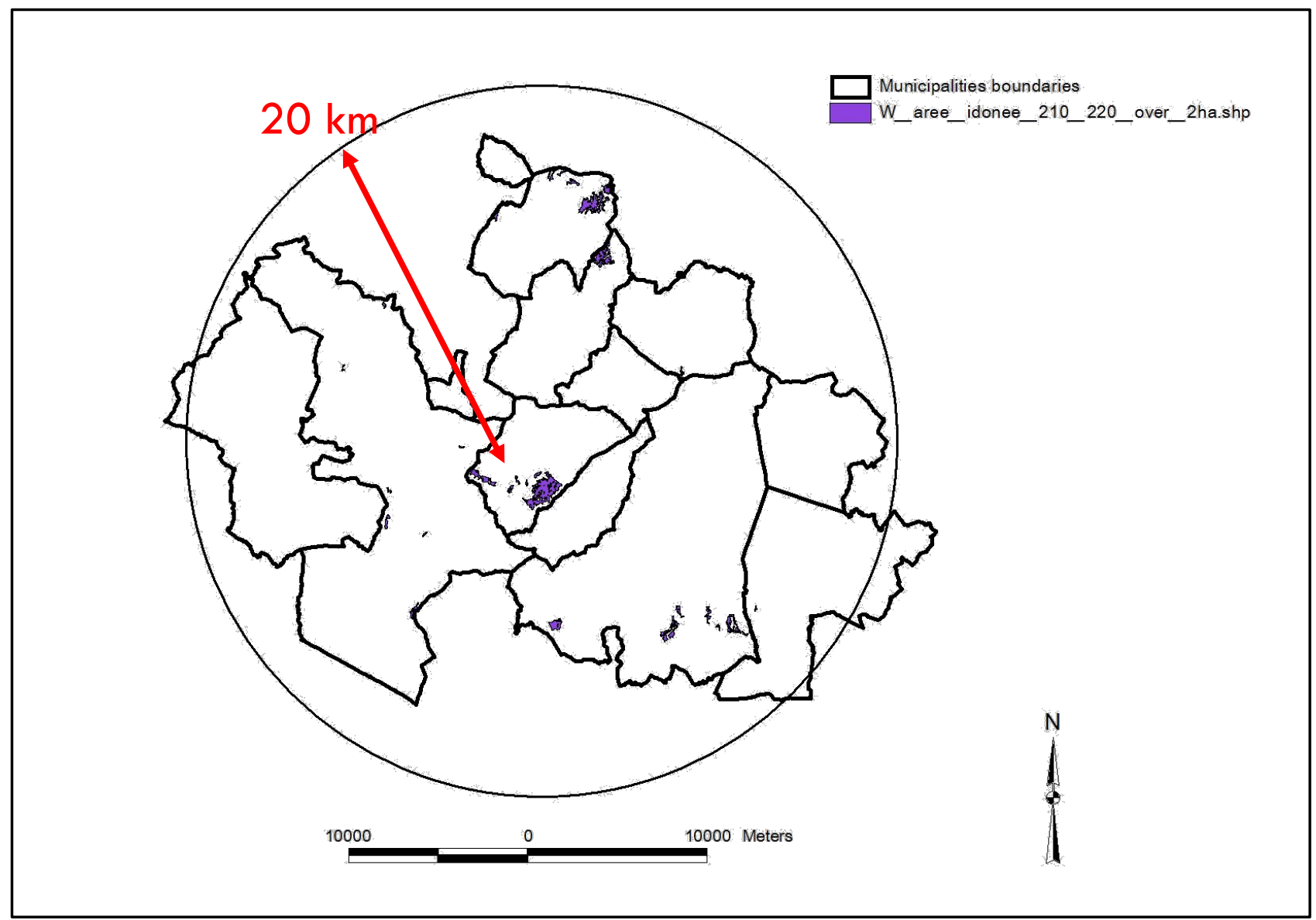

Figure 6. Locations in the agroforestry energydistrict of areas suitable for biomass plants. 


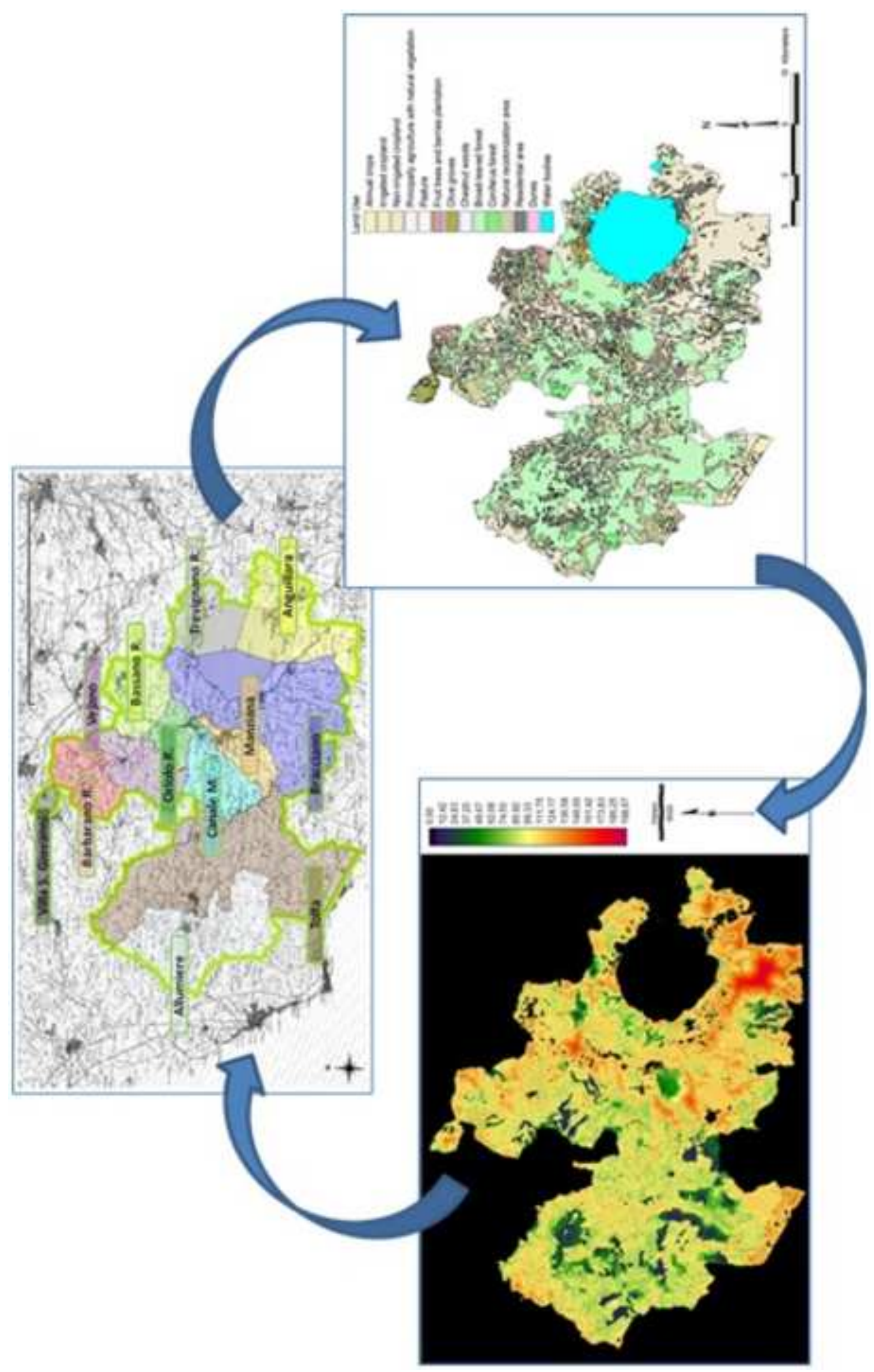




\section{HIGHLIGHTS}

The motivation factors novelty in results/ findings and significance ofresults of this works are:

- We assessed the potential amount of agro-forestry biomass of different origins in central Italy.

- The location of exist energy plants was analyzed.

- Biomass availability, energy potential and transport infrastructure were considered.

- We investigated territorial features using Multi Criteria models and GIS approaches.

- Best decisions to develop an energy plant were identified at the local scale.

Sincerely

The authors. 